\title{
WHEN IT RAINS, IT POURS: UNDER WHAT CIRCUMSTANCES DOES JOB LOSS LEAD TO DIVORCE
}

\author{
By \\ Melissa Ruby Banzhaf \\ U.S. Census Bureau
}

CES 13-62 December, 2013

The research program of the Center for Economic Studies (CES) produces a wide range of economic analyses to improve the statistical programs of the U.S. Census Bureau. Many of these analyses take the form of CES research papers. The papers have not undergone the review accorded Census Bureau publications and no endorsement should be inferred. Any opinions and conclusions expressed herein are those of the author(s) and do not necessarily represent the views of the U.S. Census Bureau. All results have been reviewed to ensure that no confidential information is disclosed. Republication in whole or part must be cleared with the authors.

To obtain information about the series, see www.census.gov/ces or contact Fariha Kamal, Editor, Discussion Papers, U.S. Census Bureau, Center for Economic Studies 2K132B, 4600 Silver Hill Road, Washington, DC 20233, CES.Papers.List@census.gov. 


\begin{abstract}
Much of the previous research that has examined the effect of job loss on the probability of divorce rely on data from the 1970s-80s, a period of dramatic change in marital formation and dissolution. It is unclear how well this research pertains to more recent trends in marriage, divorce, and female labor force participation. This study uses data from the Survey of Income and Program Participation (SIPP) from 2000 to 2012 (thus including effects of the Great Recession) to examine how displacement (i.e., exogenous job loss) affects the probability of divorce. The author finds clear evidence that the effects of displacement appear to be asymmetric depending upon the gender of the job loser. Specifically, displacement significantly increases the probability of divorce but only if the husband is the spouse that is displaced and his earnings represented approximately half of the household's earnings prior to displacement. Similarly, results show that the probability of divorce increases if the wife is employed and as her earnings increase. While the mechanism behind these asymmetric results remains unclear, these results are consistent with recent research that finds a destabilizing effect on marriages when a wife earns more than her husband.
\end{abstract}

Keywords: divorce, job loss, displacement JEL codes: J12, J63

* Melissa Ruby Banzhaf, Administrator, Atlanta Census Research Data Center at the Federal Reserve Bank of Atlanta, 1000 Peachtree St. NE, Atlanta, GA 30309. Email: mbanzhaf@frbatlanta.org. Disclaimer: Any opinions and conclusions expressed herein are those of the author and do not necessarily represent the views of the U.S. Census Bureau. All results have been reviewed to ensure that no confidential information is disclosed. The author would like to thank Animesh Giri for providing research assistance, and Kristin McCue and Laura Argys for helpful comments. The author also thanks participants at the 2012 Southern Economic Association annual meeting and seminar participants at Georgia State University and the U.S. Census Bureau for providing valuable feedback. 


\section{Section 1: Introduction}

As a result of the "Great Recession" in December 2007, 8.8 million jobs were lost. Even though the recession officially ended in June 2009 , unemployment rates have been slow to improve. Although the macro consequences of job loss have received much attention, there are also important micro consequences to be considered. One of these is the effect of job loss on marital stability.

After peaking in 1981, the average divorce rate in the U.S. population has been steadily declining. As Stephenson and Wolfers (2007) document, part of this fall is attributable to lower marriage rates in the population. However, even after controlling for declines in marriage, the divorce rate for married couples "at risk" of divorce has fallen more than twenty percent since its peak. In addition to changes in divorce, recently studies have documented changes in marital matching since the 1970s. For example, Bredemeier and Juessen (2013) find that there has been an increase in assortative mating leading to changes in the patterns of female labor force participation.

Hellerstein and Morrill (2011) have recently examined the effect of macroeconomic shocks on aggregate divorce rates and find that, at the state level, an increase in the unemployment rate is associated with a decline in divorce rates. However, less is known about the effect of job loss on the probability of divorce at the household level. Studies such as Charles and Stephens (2004) and Weiss and Willis (1997) that do examine the effect of job loss or negative income shocks on the probability of divorce rely on data from the 1970s-80s, a period of dramatic change in marital formation and dissolution. Although Doiron and Mendolia (2011) analyze job loss on family dissolution within the past decade, they use British household data and include cohabitations in their analysis. It is unclear how well their findings extend to the institutional frameworks underlying marriage and divorce, not to mention job loss, in the United States.

Why should economists care if job loss negatively affects marriage? Studies have shown divorce to have mostly negative economic and social consequences, even after controlling for selection issues. 
Many of these studies have documented negative effects of divorce on children with respect to educational outcomes (Painter and Levine 2000; Tartari 2007, Gruber 2004), earnings (Corak 2001; Kane et al. 2010), and emotional development (Gruber 2004, Amato 2000, Biblarz and Gottainer 2004). In addition, studies such as Page and Stephens (2004) have also shown negative short-term and long-term effects on family income resulting from divorce. Because job loss was so pervasive in the Great Recession and because divorce can have long-term consequences both for children and adults, it is important to better understand how job loss affects the probability of divorce in order to identify factors that might weaken this link.

In contrast to Charles and Stephens (2004) and Doiron and Mendolia (2011) who included terminations, layoffs, and displacements in their analyses of job loss, this study limits job loss to involuntary displacement resulting from reduced business demand or firm closing. I assume that this displacement is exogenous to the individual and not a result of the individual's personal characteristics or job performance. Terminations that result from firings are not included in this analysis since unobserved factors of the individual may affect both the probability of being fired and the probability of divorce (such as violent temperament, laziness, etc.), leading to biased results.

The objective of this study is to identify the circumstances under which displacement may increase the probability of divorce. Unlike Doiron and Mendolia (2011), this study examines the displacement of both husbands and wives, and determines if the sex of the job loser impacts the probability of divorce. That is, is divorce more likely to follow if the man or the woman loses a job? One important aspect of the most recent recession is that men experienced unemployment at much higher rates than women. The unemployment rate for men peaked at 10.7 percent compared with 8.3 percent for women. In contrast, the peak unemployment rates for men and women were much closer in the 2001 recession, 6.0 percent for men compared with 5.3 percent for women. Do these discrepancies in unemployment rates translate into differential rates of divorce, all other things equal? 
Second, this study analyzes how the percentage of family earnings lost from displacement affects the probability of divorce. The predictions of economic theory, discussed in section 3, are ambiguous; losing a larger proportion of family earnings could generate greater marital stress, increasing the likelihood of divorce. However, the loss of a larger percentage of family earnings also may reduce the ability of a couple to finance divorce. Taken at the limit, if the sole earner loses his or her job, it may be that neither spouse can afford to divorce due to liquidity constraints. In this study, I test for both linear and nonlinear effects of the percentage of lost earnings on the probability of divorce.

Third, this study examines how the duration of the unemployment spell affects the probability of divorce. The peak average unemployment spell at 40 weeks in the Great Recession was double the length of the peak average unemployment spell in the 2001 recession. One would expect that all else equal, longer unemployment spells would increase the probability of marital dissolution.

Finally, this study assesses whether the employment characteristics of the non-displaced spouse affect the probability of divorce. Using Census Bureau data, the proportion of dual-earner households has grown from 29 percent in 1970 to about 54 percent in 2007, the year before the Great Recession began. This trend reinforces the need for current research on the relationship between job displacement and divorce since marriages may react differently to displacement than in prior years when one-earner households were the norm.

To address these research questions, I use data from the Survey of Income and Program Participation (SIPP). The SIPP is a longitudinal household-based survey that collects information on sources of income, earnings, savings, public program participation, disability, and key demographic characteristics, such as martial history. This study pools data on married couples from the 2001, 2004, and 2008 panels of the SIPP. Each panel lasts 3 to 4 years and includes between 30,000 and 50,000 households. Thus, the data cover both the smaller 2001 recession and the more recent Great Recession, making it appropriate for studying recent trends in displacement and divorce. 
In this study, I find clear evidence that displacement affects the probability of divorce but in an asymmetric way depending upon the gender of the job loser. Specifically, displacement significantly increases the probability of divorce but only if the husband is the displaced spouse and if his earnings represent approximately half of the household's earnings prior to displacement. In addition, while longer nonemployment spells (whether spent in unemployment or out of the labor force) increase the probability of divorce if men are displaced, they appear to have no effect for women. When examining characteristics of the non-displaced spouse, the results show that the probability of divorce increases if the wife is employed and as her earnings increase.

While the exact reason for the marital break-down is unclear, these results are consistent with other recent studies showing persistent gender asymmetries in marital behavior. For example, Singleton (2012) examines the effect of spousal disability on the probability of divorce and finds that the risk of divorce increases significantly only when husbands, not wives, incur a work-preventing disability. Furthermore, Bertrand, Kamenica, and Pan (2013) examine the role of gender identity and relative incomes within households. They find substantial increases in the risk of divorce when the wife earns more than the husband, a situation that would occur if the husband is displaced and the wife is employed.

This paper is organized as follows. Section 2 provides an overview of the previous literature on job loss and divorce. Section 3 outlines a theoretical model of divorce in which the couple remains married as long as the gains to marriage are greater than zero. Section 4 discusses the estimation of a discrete-time duration model of divorce. In section 5, I describe the SIPP dataset in more detail. Section 6 provides results and section 7 concludes.

\section{Section 2: Previous Literature}

The main theory underlying divorce comes from Becker, Landes, and Michael (1977). The authors posit that a couple stays married if the expected wealth from staying married for both spouses 
exceeds the expected wealth when divorced for both individuals. In the state of divorce, the expected wealth for each spouse is a combination of the individual's expected wealth when single again (less the costs of divorce) and the expected wealth if the individual remarries. The authors use this basic model to make predictions about which factors will affect the probability of divorce, all things equal. For example, if couples make marital-specific investments, such as in children, houses, and information, they are less likely to divorce since these investments tend to increase the wealth of the married state relative to the divorced state. ${ }^{1}$ Thus, their model predicts duration-dependence in marriage since marital-specific investments increase with duration.

The Becker, Landes, and Michael model of divorce builds upon the marriage search model developed in Becker (1974). Similar to other search models, in Becker (1974), an individual incurs a cost and with some frequency draws a mate from a distribution of potential mates. The individual compares the expected wealth of marrying the drawn mate with the expected value of additional search and a different draw from the distribution. ${ }^{2}$ Individuals decide to marry if the expected wealth from marrying is greater than the value of additional search for both partners.

Thus, the decision to marry is made in a world of imperfect information. Becker, Landes, and Michael hypothesize that if the actual gains or wealth from marriage are significantly different than the expected gains, then the spouses could decide to dissolve the marriage. For example, if one spouse's earnings are much higher than anticipated at the time of the marriage, the value of staying married is higher because they both gain by the increased wealth. However, for the spouse who has obtained the higher earnings, the expected wealth when divorced is also higher both because his wealth is higher if

\footnotetext{
${ }^{1}$ Some marital-specific investments, such as information about one's spouse, increase the expected wealth of the marriage state but have no effect on the expected wealth of the divorced state. Other marital-specific investments, such as children, increase the expected wealth of the marriage state and also decrease the expected wealth of the divorced state since the costs of having children are higher in a divorced state and can lower the expected wealth of remarriage.

${ }^{2}$ Because of positive assortative mating, draws that have similar characteristics to the searcher yield higher expected wealth than other draws.
} 
single again and because he may be able to obtain a better match from the distribution of possible spouses. Thus, the larger the difference between expected and actual wealth, the more likely it is that divorce occurs.

Several empirical studies have tested this hypothesis yielding conflicting results. Weiss and Willis (1997) used the National Longitudinal Study of the High School Class of 1972 to investigate the role of surprise in marital dissolutions. The authors examined how unexpected changes in spouses' earning capacities influenced the divorce hazard. They found that an unexpected increase in the husband's earning capacity reduced the divorce hazard whereas an unexpected increase in the wife's earning capacity increased the divorce hazard. These results appear consistent with a model of household production in which spouses specialize. If a man and woman marry with the expectation that the husband will specialize in market work and the wife will specialize in nonmarket work, then an unexpected increase in earnings capacity for the husband reinforces this model, whereas an unexpected increase in earnings capacity for the wife diminishes the gains to this type of marriage.

For unexpected declines in earnings capacity, Weiss and Willis (1997) results support the opposite conclusion. That is, that if the husband loses his job (an unexpected decrease in earning capacity), the probability of divorce increases, but if the wife loses her job, the probability of divorce decreases. The magnitude of the effects are not symmetrical and depend upon interactions between both spouse's earning capacities.

Charles and Stephens (2004) focus solely on negative income shocks and examine how shocks arising from two sources, layoff/plant closings and physical disability, affect the probability of marital dissolution. Using the Panel Study of Income Dynamics (PSID), they find no significant effect for either physical disability or plant closings (which they treat as exogenous layoffs or displacements) on the probability of divorce for men or women. Thus, their results suggest that while displacement may reduce the current gains of marriage (through lower income in the current period), the future gains of 
marriage remain relatively unaffected. This result does not apply to job losses that result from layoffs or firings, both of which they assume are correlated with the individual's underlying traits. In these cases, they find that layoffs/firings increase the probability of divorce, particularly for husbands. They argue that this type of non-exogenous job loss may reveal information about the non-economic suitability of a mate, i.e. the match, that is more important than income losses in causing divorce.

Similarly, Doiron and Mendolia (2011) analyze how the probability of family dissolution changes under various types of job losses, such as firings, temporary layoffs, and exogenous, permanent displacement. They include the dissolution both of marriages and cohabitations in their analysis but only examine the effect of the husband's job loss on these unions. They find that firings and temporary layoffs have positive, significant effects on probability of family dissolution, whereas exogenous displacements (known as "redundancies" in Great Britain) have positive but insignificant and short-lived effects on family dissolution. Their results provide further evidence that the reason for job loss matters when considering effects on the family. ${ }^{3}$

This study differs from the previous literature on negative income shocks and marital stability in several important ways. First, the conclusions drawn from the previous literature rely upon older data. For example, Weiss and Willis use data from individuals who graduated in the high school class of 1972. Many of these individuals married and divorced during the 1970s and early 80 s - the era of peak divorce rates. Given that the trends in marriage and divorce rates have fallen in the past twenty-five years, it is unclear if their results would pertain to more recent marriages. Indeed, some researchers, such as Isen and Stevenson (2011) and Lundberg (2012), have suggested that the changes in marriage and divorce trends reflect a changing model of marriage from one of specialization in household production to one

\footnotetext{
${ }^{3}$ Related research provides insight into the effects of other economic events on marital stability. Hankins and Hoekstra (2011) find that positive income shocks of $\$ 25,000$ to $\$ 50,000$ from winning the lottery do not significantly change divorce rates, regardless of which spouse won the prize. Farnham, Schmidt, and Sevak (2011) investigate how changes in house prices affect marital stability. The authors find that the marital-specific investment of owning a home produces more stable marriages in down markets, since the transaction costs of disposing of this investment are often quite high.
} 
of consumption, in which couples marry and divorce based on utility maximization. If this is so, the results from Weiss and Willis may not be applicable to today's couples.

Second, while Charles and Stephens (2004) use somewhat more recent data from the Panel Study of Income Dynamics, 1968-93, their sample consists disproportionately of longer-lasting marriages since they drop from analysis marriages that dissolved before the first collection of marital history in 1985. Yet theory suggests that the negative income shocks from job loss may have larger effects on marriages of shorter durations since these couples have not accumulated as much marital-specific capital. In contrast, this study uses data from the three most recent panels of the SIPP and analyzes the effect of job loss and marital dissolution from 2001 to the present, including the Great Recession. Moreover, in this sample, the durations of marriages are representative of the U.S. population. Thus, I expect the results from this analysis to be more relevant in understanding the current relationship between job loss and marital dissolution.

Finally, this study does not simply attempt to answer the question "does displacement affect the risk of divorce" but also tries to identify the circumstances under which displacement may affect the probability of divorce. Providing greater insight into this relationship may help policy-makers determine mechanisms to stabilize marriages during periods of wide-spread job loss.

\section{Section 3: Theoretical Model}

This section presents a utility-based model of divorce in which the couple compares the gains of staying married with the utility derived from the alternative state of divorce. This model builds upon a model of divorce presented in Charles and Stephens (2004). In this model, a married couple $i$ with members $j=\{h, w\}$ derive utility from their income or earnings $Y_{j t}$ and a stock of marital-specific capital, $K_{i t}$, such that $U_{i t}=U\left(Y_{h t}, Y_{w t}, K_{i t}\right)$. The stock of marital capital in time $t, K_{i t}$, reflects an accumulation of marital-specific investments, such as children, home equity, and shared interests that are couplespecific. Utility is strictly increasing in all of the arguments, such that $U_{1}>0, U_{2}>0$, and $U_{3}>0$. 
In addition, both permanent and temporary shocks may affect the utility of being married. Let $\mu$ represent the latent match quality, known by the couple but unobserved by the researcher, and let $\varepsilon_{i t}$ represent period-specific idiosyncratic shocks that affect the utility of being married. Examples of these idiosyncratic shocks could include illness or death of a family member, unexpected pregnancy, winning the lottery, etc.

If divorced, the individual could be single or remarried to a different spouse. The individual derives alternative utility $A_{j t}\left(Y_{j t}\right)$ which is solely dependent upon the individual's income, not the former spouse's. In this simplified model, the individual's income $Y_{j t}$ is the primary characteristic that determines the quality of a match with a new spouse. Utility in the divorced state is also affected by the costs of divorce $C\left(K_{i, t}\right)$ which are shared by spouses and vary by the stock of capital from marriage $i^{4}$ Costs are strictly increasing in marital-specific capital, $C^{\prime}(K)>0$. Consequently, the model suggests that the costs of divorce are higher when the couple has children or shared wealth.

Using this notation I can summarize the gains of marriage, $G_{i t}$, for couple $i$ in period $t$ as a sum of the current utility derived from staying married, and the maximal expected discounted value of future utility conditional on the current information set $I_{t}$ and on optimal decisions being made in future periods. That is, 
probability of staying married. In addition, the model shows the gains of marriage are lower, and therefore the probability of divorce is greater, for marriages with low quality matches $\mu$.

Turning to the primary research questions of this study, the model predictions are ambiguous about the effect of job displacement on the probability of divorce. If spouse $j$ is laid-off exogenously, i.e., through no fault of his or her own, then $Y_{j t}$ may fall or even be zero. This decrease in earnings lowers the current utility derived from marriage $i$ since 
not necessarily be equal to 
In both (11) and (12), the likelihoods of the observed spells are conditional on the unobserved matchspecific error component, $\mu_{i}$. To obtain unconditional functions, I treat $\mu_{i}$ as a random effect and integrate it out using random effects probit. Thus, the unconditional sample likelihood function for $N$ couples is 
does increase the risk of divorce, the shortness of the panel suggests that the effect is likely to be underestimated. While the length of the panel may be a disadvantage for the SIPP, the richness of the information collected (marital history, employment, asset information), the frequency of the data collection (every four months), and the timeliness of the data (spanning the most recent recessions) make the SIPP particularly useful for this study.

The SIPP collects detailed employment information for each person in the household age 15 years or older for up to two jobs in a four-month interview period. If an individual stops working for an employer, the survey collects the main reason for leaving. These reasons include "on layoff, retirement or old age, childcare problems, other family/personal obligations, own illness, own injury, school/training, discharged/fired, employer bankrupt, employer sold business, job was temporary and ended, quit to take another job, slack work or business conditions, unsatisfactory work arrangements (hours, pay, etc), quit for some other reason." Recall that this study considers displacement to be involuntary job loss resulting from reduced business demand or firm closing. The displacement is assumed to be exogenous to the individual and not a result of the individual's personal characteristics or job performance. Therefore, I use the responses that include "employer bankrupt, employer sold business, slack work or business conditions" to determine when an individual has been displaced. ${ }^{7}$ In a follow-up robustness check, I further restrict the definition of displacement to only include those who left their jobs because of "employer bankrupt" or "employer sold business".

At every interview, the SIPP records the marital status of each individual in the household. In addition, in the eighth month of the survey, the SIPP collects a detailed marital history on each individual. From this information, I calculate the duration of the current marriage and obtain important

\footnotetext{
${ }^{7}$ I do not classify the answer choice "on layoff" as a displacement for several reasons. First, some respondents may have indicated that they were "on layoff" when they were actually terminated or discharged for cause. Second, some respondents were categorized as "on layoff" if they were temporarily displaced from their employer but expected to be recalled within 6 months. Since I assume the response within a marriage could be quite different depending upon whether the displacement is expected to be temporary or permanent, 1 exclude these couples from the displacement analysis.
} 
martial history variables, such as prior divorce, which may influence the risk of divorce in the current marriage.

I limit the estimation sample to couples who were married in the first month of the survey. A marriage spell could end in one of three ways. First, the couple could dissolve their marriage by separating or divorcing. Second, the marriage spell would end if one of the spouses dies. Finally, the marriage spell would be right-censored if the couple is still married at the end of the survey or the last period in which they are observed. ${ }^{8}$ For couples whose marriages end in divorce or death, I do not follow subsequent marriages. Thus, marriage spells are independent across individuals.

I define the period of marital dissolution as the first month in which at least one spouse indicates that his or her marital status is either "separated" or "divorced." ${ }^{9}$ I include marital separations in the definition of "divorce" for practical reasons. First, I observe frequent inconsistencies in how respondents code their marital status. For example, for the same month, one spouse will give a marital status of "separated" while the other will indicate a marital status of "divorced." Second, only a small proportion (about twelve percent) of couples reconcile after being separated. Thus, consistent with other studies, the first month of separation is the period in which the marriage dissolves.

I eliminate couples from the estimation sample based on several criteria. First, couples are dropped from the sample if they have missing or inconsistent marital histories. Second, the sample is restricted to couples whose spouses are under the age of 62 at the beginning of the survey in order to focus on working-age couples who are at risk of displacement. Finally, I exclude couples in which a

\footnotetext{
${ }^{8}$ Sometimes a couple misses an interview but is interviewed again in future waves. If a gap appears in their marriage spell, the spell is censored at the period before the gap begins.

${ }^{9}$ In addition, I also code the couple as divorcing in two other uncommon cases: 1) a spouse indicates a marital status of "married, spouse absent" and also indicates that the main reason he or she left the household was separation or divorce, and 2) a respondent changes spouses from one month to the next without any intervening period of divorce. I assume that these are coding errors and define the couple as divorcing in the last period they are observed married.
} 
spouse has been fired or laid-off in order to have a clearer analysis of the effects of displacement on divorce. The resulting sample consists of 31,850 couples and 992,539 monthly observations. ${ }^{10}$

Figure 1 shows the estimated annual hazard rate for divorce by marital duration. ${ }^{11}$ The hazard rate is the probability of divorce conditional on the marriage surviving to the specified marriage duration. In Figure 1, the estimated hazard changes dramatically during the first 10 years of marriage, peaking at around 2 years before falling steeply. These results are generally consistent with marriage as a matching model in which spouses learn about their match in the first years of marriage and dissolve bad matches. After the first 10 years of marriage, the divorce hazard continues to fall although more gradually.

Table 1 provides descriptive statistics on the entire sample and each panel separately. These statistics are weighted using sample weights from the first period for each couple. The first set of statistics in Table 1 summarizes the matching behavior of couples in the sample. In general, the literature has shown that positive sorting on match characteristics produces more stable marriages (Becker, Landes, and Michael 1977; Weiss and Willis 1997). In this sample, 92 percent of the sample shares the same race, lower than the 97 percent found by Charles and Stephens (2004) in their PSID sample spanning 1968-1993, suggesting that positive sorting on race is falling gradually over time. Approximately 60 percent of the sample shares the same education level with the highest proportion, 23 percent, both having a college degree. Finally, the average age of spouses at marriage is about 2.5 years higher for spouses in this sample compared with Charles and Stephens (2004), reflecting both a well-documented trend in delayed marriage (Stevenson and Wolfers 2007) as well as a smaller proportion of first-time marriages (67 percent versus 80 percent in Charles and Stephens 2004).

\footnotetext{
${ }^{10}$ The number of months in which couples are observed depends upon the maximum length of the survey panel as well as the number of periods in which they are observed in the panel.

${ }^{11}$ The hazard is estimated using a weighted kernel density estimate of $d_{t} / n_{t}$ where $d_{t}$ is the number of divorces occurring at marriage duration $t$ and $n_{t}$ is the number of couples at risk just prior to $t$.
} 
Table 1 also summarizes statistics related to marital-specific investments. Table 1 shows that the mean duration of the marriage spell in this sample is about 17 years. The median durations of completed spells (not shown) are 16 years for those who do not divorce and 9.5 years for those who do. Also, a little over two-thirds of the couples in this sample have children living in the household, and for these couples, the average number of children is about 2 . Step-children represent investments from previous marriages or relationships that may affect the stability of the current marriage. Although approximately a third of couples include a spouse who has been previously divorced, a much smaller percentage, about eight percent, have step-children living in their households. For these couples, the average number of step-children is about one and a half.

In addition to children, couples may invest in other marital-specific capital such as homes or other assets. Approximately $84 \%$ of couples in this survey own their own home. The percentage of homeowners peaks in the 2004 Panel and declines in the 2008 Panel. This trend is consistent with the general changes in homeownership (i.e., falling housing prices and increased foreclosures) which occurred during the Great Recession.

In the quarterly surveys, the SIPP does not collect data on couple's assets but does collect information on interest and dividend income. ${ }^{12}$ Since these measures are correlated with asset levels, investment income provides a suitable proxy for investment capital. Approximately seventy percent of couples have investment income, but like housing prices, this number peaked in the 2004 panel and declined in the 2008 Panel, also reflecting the influence of the Great Recession.

The last set of statistics in Table 1 summarizes the divorce and displacement events, the main variables of interest, in the sample. On average, couples are observed for approximately 31 months. During this period, a little over four percent of the couples in this sample divorce and about six percent of couples experience a displacement. If no displacement occurs, about four percent of couples in this

\footnotetext{
${ }^{12}$ The SIPP does collect information on assets but only in two or three surveys per panel, whereas investment income is collected in every survey.
} 
sample are observed to divorce. If a displacement occurs, the proportion of those divorcing rises to 4.6 percent. Chi-square tests show that these proportions do not differ significantly.

Many of the displacement-related variables in Table 1 confirm the general recession trends observed elsewhere. For example, the percentage of couples who experience a displacement is lowest in the 2004 Panel, 4.5 percent, and highest in the 2008 Panel, 6.8\%. Furthermore, many studies have reported that the Great Recession affected males disproportionately compared with previous recessions. The statistics in Table 1 confirm this finding since in the 2008 Panel, husbands were displaced in about two-thirds of couples who experienced any displacement. Finally, the length of the observed nonemployment spell following displacement is significantly greater in the 2008 Panel, as expected. This result holds whether these spells were spent in predominantly in unemployment or outof-the-labor force (OLF).

The descriptive statistics in Table 1 capture many of the important trends of the Great Recession - higher rates of displacement especially for men, longer unemployment spells, and lower home ownership rates. In addition, the simple means suggest that divorce rates may be higher for those that are displaced, in at least some years. In the next section, I will examine the relationship between these variables and the probability of divorce in a statistical framework which controls for differences across couples.

\section{Section 6: Results}

In the results presented in section 6.1 , I control for match quality in equation (4) using a rich set of covariates, similar to Charles and Stephens (2004), but do not attempt to control for any portion of the match-specific component that is unobserved. In the robustness checks presented in section $6.2,1$ assess how the results change with the changes to the definition of job loss and discuss controls for unobserved heterogeneity. 


\subsection{Main Results}

Table 2 shows results from estimating a basic hazard probit model of divorce with only demographic covariates and no displacement controls. Both models (1) and (2) contain a rich set of covariates that correspond to theory or past research. They also include fully-saturated interactions between race and education covariates as well as controls for state-specific time-invariant effects, yearmonth time effects, and state-specific linear time trends (these are not reported but available from the author). Model (1) leaves out the effect of spousal earnings on the probability of divorce while model (2) includes them. Since earnings may be confounded with the outcome of interest, displacement, I leave earnings out of subsequent estimations that include displacement variables. Results are not sensitive to the exclusion of earnings variables.

The results in Table 2 show that this basic model of divorce conforms well to theoretical predictions. The duration dependence in marriage is captured through the use of cubic splines with nodes at $3,5,7,10,15,20,25$, and 30 years of marriage. The estimated coefficients on these splines reflect a complex pattern of duration dependence with the divorce hazard peaking between 5 to 7 years, and again around 15 to 20 years of marriage after controlling for differences in observables.

The model results reveal that marital-specific investments, such as the number of children and owning a house tend to significantly decrease the probability of divorce, although the effect of investment income (a proxy for financial assets) while negative is insignificant. Unlike previous research, the effect of children on the probability of divorce is allowed to vary by whether the children in the household belong to both spouses biologically or only one. If the children belong to both spouses' biologically (or are adopted), having more children is associated with a significantly lower probability of divorce as evidenced by the negative coefficient on totalkids ${ }^{13}$. The coefficients on the quadratic

\footnotetext{
${ }^{13}$ The variable totalkids includes the total number of both biological children and step-children living in the household, but because the variable stepkids is also included in the model, the variable totalkids essentially isolates the effect of biological children on the probability of divorce.
} 
stepkids variables represent the marginal effect the number of step-children living in the household has on the probability of divorce. Not only does the number of step-children significantly increase the probability of divorce (albeit at a declining rate) but the magnitude of the stepkids coefficient is more than three times that of totalkids. This result implies that step-children have a much larger impact on the stability of a marriage than biological children do.

In addition, controlling for the presence of step-children in the model also has an important effect on the priordiv coefficient, an indicator variable for whether either spouse has been previously divorced. Previous studies such as Charles and Stephens (2004) have found a significant and positive association between being previously divorced and the likelihood of the current marriage ending. In estimates not shown, the coefficient on priordiv becomes positive and highly significant if the variable stepkids is dropped from the model, consistent with Charles and Stephens (2004). Yet Table 2 shows that including controls for the presence of step-children causes the coefficient on priordiv to become insignificant, implying that it is not a prior divorce per se that destabilizes the current marriage but the presence of marital-specific capital from the prior marriage, such as step-children. Thus, these results indicate that not all children are "equal" when modeling divorce and treating them as such obfuscates important effects.

Unlike Hellerstein, Morrill, and Zou (2013) who find a negative association between the unemployment rate and the probability of divorce, I find no statistically significant relationship between the unemployment rate (here measured as a lagged three month average of the monthly unadjusted state unemployment rate) and a couple's hazard of divorce after including controls for state, time, and state-specific time trends. ${ }^{14}$ This result is consistent with Arkes and Shen (2010) who tested for the effects of the state and national unemployment rates on divorce using micro-level data (the National Longitudinal Survey of Youth 1979). They found no effect of the unemployment rate on the hazard rate

\footnotetext{
${ }^{14}$ Results are not sensitive to the exact form of the unemployment variable (contemporaneous versus lagged).
} 
of divorce for most marriages. These conflicting results suggest further research would be useful in understanding the discrepancies.

In equation (2) in section 3, the gains from marriage depend upon both the husband's and wife's income. To approximate income, model (2) in Table (2) includes quadratic specifications of each spouse's earnings and an interaction term between the two. This specification is similar to that used in Weiss and Willis (1997) except that they used predicted earnings at the time of marriage instead of actual earnings. The coefficients on the husband's earnings variables suggest that all else equal, increasing earnings reduce the probability of divorce though not significantly. The opposite is true for the wife's earnings - as her earnings increase, the probability of divorce increase. These results are similar in sign to what Weiss and Willis found using predicted earnings. While they found a positive interaction between the wife and husband's predicted earnings, I find a negative though insignificant effect suggesting the spouse's earnings influence the divorce probability independently of each other.

\subsubsection{Displacement - One Spouse versus Both Spouses}

The first model in Table 3 includes all of the basic demographic and control variables from model (1) in Table 2, but also adds the absorbing displacement indicator variable from the period in which the spouse loses his/her job due to displacement (as opposed to quitting or being fired). The coefficient on displaced indicates that displacement to one or both spouses significantly increases the probability of divorce. In model (2), I also include the earnings variables from model (2) of Table 2 to ensure that the displaced coefficient is not simply reflecting a correlation with the earnings variables. In fact, this appears not to be the case, since the coefficient on displaced is still positive and significant. Because the actual earnings variables do not appear to influence the displacement coefficient, I drop these variables from the remainder of the analysis in order to focus on varying the job displacement specification. 
In the first two models of Table 3, the displacement variable captures the effect if either spouse is displaced. However, it could be that the effect on the probability of divorce differs depending upon whether one or both spouses' lose their jobs. Theory suggests that although the utility of the current marriage would fall so would the utilities of both spouses in the divorced state. Although the effect that dominates is still theoretically ambiguous, it seems likely that divorce would be less likely to occur when both spouses lose their jobs since it would be more difficult to finance the costs of divorce. To test for these effects, model (3) interacts the displacement variables with an indicator variable identifying couples in which both couples experience displacement. The result of the interaction suggests that couples in which both spouses lose their jobs are less likely to divorce than couples in which only one spouse is displaced, though the difference is not significant.

For the remainder of the analysis, I exclude couples in which both spouses are displaced (about five percent of all couples who experienced any displacement) in order to focus on how other circumstances, such as the sex of the job loser, affect the risk of divorce. The first model in Table 4 estimates the original displacement model in Table 3 (model (1)) on the reduced sample of 31,196 couples. Consistent with the previous results, the coefficient on displaced confirms that the job loss of only one spouse significantly increases the divorce hazard. Indeed, calculating the average partial effect of the displaced coefficient indicates that displacement increases the average predicted probability of divorce by half of a percentage point annually. Because the baseline predicted probability of divorce is relatively low, the effect of displacement translates into a $37 \%$ increase in the predicted probability of divorce, all else held equal.

In the second model of Table (4), the effect of displacement on the probability of divorce is allowed to vary by the sex of the job loser. ${ }^{15}$ The estimated coefficients reveal that only when the husband is the spouse displaced does the probability of divorce significantly increase. Moreover, the

\footnotetext{
${ }^{15}$ The coefficient displaced*wife is interpreted as the effect on the divorce risk when the wife is the spouse that is displaced. Likewise, displaced*husband represents the effect on the divorce risk when the husband is displaced.
} 
magnitude of the effect is over four times as large for husbands as for wives. When the husband is displaced, the average predicted probability of divorce increases by 0.9 percentage points annually, leading to almost a $56 \%$ increase in the probability of divorce relative to couples who experience no displacement. ${ }^{16}$ These results suggest that the sex of the job loser does indeed matter for predicting divorce. Consequently, all subsequent models will allow effects to differ between husbands and wives.

The final model in Table 4 allows the effect of displacement on the probability of divorce to vary by the state unemployment rate. The unemployment rate reflects general macroeconomic conditions in the state and it is possible that couples may react differently to displacement in different macroeconomic environments. The negative coefficients on the unemployment rate interactions reveal that the probability of divorce is still positive following displacement but falls as the unemployment rate increases. However, the lack of statistical significance for either spouse suggests that macroeconomic conditions do not represent a substantial factor in these divorce decisions.

\subsubsection{Proportion of Lost Earnings}

Table 5 examines how the proportion of earnings lost because of the displacement affects the probability of divorce. As in previous tables, the first model in Table 5 represents the basic hazard model of divorce with an intercept shifter for displacement. In the second model, the displacement intercept is interacted with a variable that quantifies how the proportion of lost family earnings impacts the probability of divorce. The variable lostearn captures the proportion of family earnings lost in the period immediately after the displacement and thus represents the initial shock to family earnings from the displacement. The coefficient on displaced*lostearn indicates that the proportion of lost earnings does not significantly affect the likelihood of divorce. Model (3) allows the marginal effect of lost

\footnotetext{
${ }^{16}$ While this estimate appears quite large, it is generally consistent with other recent results in this area. Bertrand, Kamenica, and Pan (2013) find that if the wife earns more than her husband, the likelihood of divorce increases by 50 percent. While they are looking at changes in the probability divorce over a five year time frame, we can expect a negative shock such as displacement to have a more immediate effect on marriage stability.
} 
earnings to vary by the sex of the job loser. Here again, though, there seems to be no significant additional effect of the proportion of lost earnings on the divorce probability.

In Table 5, the proportion of lost earnings was modeled linearly. It may be that the proportion of lost earnings affects the divorce hazard nonlinearly. Consequently, in Table 6, models (2) and (3) allow the effect of lost earnings on divorce to vary depending upon whether the proportion of earnings lost falls into one of four categories: minor loss ( 0 to 0.40 of family earnings), equal loss ( 0.40 to 0.60 ), major loss (0.60 to 0.99$)$ or complete loss (1.00, i.e., the sole earner loses his or her job). The results from model (3) in Table 6 reveal that the proportion of lost earnings does impact the divorce hazard nonlinearly by the sex of the displaced spouse. The probability of divorce significantly increases when the husband is displaced and the proportion of earnings lost is approximately one-half. Thus, Table 6 suggests that not only does the sex of the job loser matter in predicting divorce but the earning structure of the marriage prior to divorce. Marriages most at risk of divorce following displacement appear to be ones in which both spouses contributed somewhat equally to the financial resources of the household.

\subsubsection{Employment Characteristics of the Other Spouse}

Previous specifications have examined how characteristics of the displaced spouse or the displacement itself affect the probability of divorce. The specifications in this section consider the employment status and earnings of the spouse who was not displaced. The findings from these models contribute to a further understanding of how displacement may affect marital dissolution.

Table 7 explores how the employment status of the non-displaced spouse affects the probability of divorce. As in previous tables, the first model in Table 7 specifies results for the basic displacement model for comparison. In the second model, the marginal effect of displacement is allowed to vary by whether the non-displaced spouse is employed or not (i.e., the variable spouse_employed equals one if the non-displaced spouse is employed and zero otherwise). The estimated coefficient on the interaction 
term displaced*spouse_employed indicates that the probability of divorce is not significantly higher when the non-displaced spouse is employed than when he/she is not. However, the total effect on divorce (displaced + displaced*spouse_employed) is statistically significant at the one percent level implying that the risk of divorce increases for couples in which the non-displaced spouse is employed relative to couples who do not experience displacement. Model (3) of Table 7 shows that the effect is driven entirely by the displacement of husbands since the total effect when the wife is displaced is not significant different that couples who experience no displacement.

Table 8 consists of a similar analysis to Table 7 except that these specifications examine the effect of the non-displaced spouse's earnings on the probability of divorce instead of simply whether or not the non-displaced spouse was employed. These results are analogous to those found in the previous table. The probability of divorce significantly increases with the non-displaced spouse's earnings but only when the displaced spouse is the husband. This result is highly robust to changes in specification in addition to the the sample as will be seen in section 6.2.

\subsubsection{Duration of the Unemployment Spell}

As has been widely documented, the Great Recession was not only characterized by widespread unemployment but also unemployment spells of unusually long duration. It is natural to wonder how these longer spells affect the risk of marital dissolution. To investigate this issue, I define the period between displacement and subsequent employment as a nonemployment spell. If I do not observe subsequent employment, then the individual remains nonemployed until the last period of observation. I then classify this spell as unemployment if the respondent spent the majority of periods looking for work and OLF otherwise. ${ }^{17}$

\footnotetext{
${ }^{17}$ I experimented with other rules for separating spells into unemployment and OLF but did not find results sensitive to the rule used.
} 
The first column in Table 9 suggests that the marginal effect of an extra month of nonemployment on the probability of divorce is not statistically significant. However, it may be that effects on divorce differ depending upon whether the spouse spent the spell looking for work versus being OLF. Therefore, model (2) allows this effect to vary depending upon the type of spell. The results from model (2) suggest that the risk of divorce is not sensitive to whether the spouse spent the majority of the spell unemployed or OLF. Additionally, when these results are allowed to vary by the sex of the displaced spouse as in model (3), we find that an extra month spent in unemployment or OLF increases the probability of divorce but only when the husband is displaced. Somewhat surprisingly, the distinction between unemployment and OLF does not appear meaningful for displaced husbands as the difference between the two coefficients is not statistically significant.

A fairly consistent pattern emerges from this and the previous set of analyses. Namely, that divorces are more likely to occur when husbands rather than wives are the displaced spouse. Moreover, the marriages most at risk of divorce appear to be those in which the wives are not only employed but a relatively equal wage earner prior to displacement. Finally, both the wife's earnings and the length of the husband's nonemployment spell appear to significantly increase the divorce hazard.

This study most closely resembles those by Charles and Stephens (2004) and Doiron and Mendolia (2011). In their studies, they examine the effect of different types of job loss, including displacements (or redundancies in the Doiron and Mendolia study) and terminations, on the probability of divorce. While they find that terminations or firings increase the divorce hazard, they find no significant effect for displacements. In contrast, I focus solely on displacements and find positive significant effects on the divorce hazard under certain circumstances. My more nuanced finding could reflect the more recent trends both in marital formation, female labor force participation, and job loss compared to the $1968-93$ period studied by Charles and Stephens (2004). In comparing my results with 
Doiron and Mendolia, it is difficult to assess how including cohabiting couples in their analysis affects their results.

\subsection{Robustness Analysis}

While I have limited the definition of job loss to reasons that I believe are exogenous to the qualities and performance of the individual ("employer bankrupt, employer sold business, slack work or business conditions") it may be that some of these reasons do not reflect true displacement, especially if the individuals displaced under "slack work or business conditions" were less productive than their retained counterparts. When Charles and Stephens (2004) limited their definition of job loss to plant closings and bankruptcy (events they assumed to be truly exogenous to the individual), they found that there was no significant impact of job loss on the divorce hazard for either spouse. To test the robustness of the results presented in section 6.1 , in this analysis I similarly restrict job loss to only reasons of "employer bankrupt" and "employer sold business."

Table 10 presents results using this more restrictive definition. Limiting job loss to only "employer bankrupt" and "employer sold business" reduces the proportion of the sample experiencing a displacement substantially from 5.6 percent to 0.42 percent. The results in model (1) and (2) suggest that, as in Charles and Stephens (2004), displacement does not significantly affect the divorce hazard even when allowing for differential effects by sex of the displaced spouse. However, whereas Charles and Stephens found a negative effect of plant closings on divorce for men, I find a positive effect, consistent with the previous results found in section 6.1.

Unfortunately, the reduced sample size of couples experiencing displacement under the more restrictive definition prevents estimation of many of the models in the previous section. However, model (3) attempts to reproduce the analysis in column (3) of Table 8, specifically estimating how the earnings of the non-displaced spouse affect the probability of divorce. The positive significant coefficient on displaced*spouse_earn*husband support previous results showing the divorce 
significantly increases with the wife's earnings when her husband is displaced. While it would be nice to test the robustness of more of the previous results, this finding confirms that it was not a broader definition of displacement that was driving the highly significant, positive effect of spousal earnings on divorce.

Another assessment of the robustness of the main results involves controlling for couple i's unobserved match characteristic $\mu_{i}$. As discussed in the estimation section, the unobserved match characteristic can be integrated out of the likelihood function using random effects yielding consistent coefficients (Wooldridge 2010). ${ }^{18}$ Tables 11 and 12 re-estimate relevant probit models from section 6.1 but control for random effects. ${ }^{19}$ Table 11 shows the results of re-estimating models (1) and (2) from Table 4 (which include intercept shifters for any displacement and displacement by sex of the displaced spouse), and model (3) from Table 9 (which allows the probability of divorce to vary by the duration of the husband's unemployment or OLF spell). The sign and significance of the coefficients in Table 11 are consistent with those previously estimated suggesting that while unobserved heterogeneity is present, according to the likelihood ratio test that $r h o=0$, it does not affect the main results. Table 12 reproduces estimations from model (3) of Table 6 (which allows the probability of divorce to vary non-linearly by the proportion of earnings lost from displacement) and model (3) of Table 8 (which allows the probability of divorce to vary by the earnings of the non-displaced spouse). The results in model (2) of Table 12 reveal that while the effect on the divorce risk is still positive when husbands are displaced who contributed approximately half the family's earnings prior to displacement, this result is no longer statistically significant as it was in Table 6. However, model (3) in Table 12 confirms the robustness of the finding

\footnotetext{
${ }^{18}$ There are two other ways to control for the unobserved heterogeneity across couples: discrete-choice fixed effects estimators and random or fixed effects in the linear probability model. However, the combination of the large sample size ( $n>31,000$ couples) and the low frequency outcome of the divorce dependent variable (with no variation in the panel for couples who do not divorce) render these estimators unfeasible for this application. ${ }^{19}$ Although I would have preferred to re-estimate the exact specifications in section 6.1 but controlling for random effects, that was not always possible due to difficulties with convergence. While all of the models in Tables 11 and 12 control for the base variables and state and month-year effects, I have dropped the state-linear time trend interactions. In addition, in some models I have had to limit the displacement-related interactions to the most relevant variables.
} 
the husband's displacement increases the probability of divorce as the wife's earnings increase since this coefficient (displaced*spouse_earn_husband) remains positive and significant at the 1 percent level.

In sum, the pattern of results appears fairly similar between the models that do and do not control for unobserved heterogeneity. Overall, this analysis suggests that ignoring unobserved heterogeneity in estimation in section 6.1 does not appear to be driving this study's main results.

\section{Section 7: Discussion of Results}

This study points to several interesting findings and areas for further research. First, this study finds that there is an asymmetry in the way job loss is viewed within the marriage. Whereas a wife's displacement appears to have no significant effect on the probability of divorce, a husband's job loss can destabilize the marriage when the wife is also employed and as her earnings increase. This results suggests that at least for some marriages, the husband's earning capacity is still of primary importance in the gains to being married. When this ability falls, even through no fault of his own, the marriage is more likely to dissolve. This result is consistent with a theory of gender identity and relative income posited by Bertrand, Kamenica, and Pan (2013) in which couples have an aversion to the wife earning more than the husband. The authors find that when the wife earns more than the husband (a departure from traditional gender roles) the likelihood of divorce substantially increases.

A separate but related reason for the observed gender asymmetries may be that women are better than men at substituting home production for market production when displaced. If this is true, then we would expect the gains to marriage to fall less when wives rather than husbands are displaced and thus would expect to observe fewer divorces.

Second, previous studies such as Charles and Stephens (2004) and Doiron and Mendolia (2011) have suggested that their positive, significant results for terminations/layoffs versus displacements on the probability of divorce is due to the negative signal that terminations provide regarding a spouse's suitability and future earning capacity. While this may be true, this study finds that job losses may have 
significant effects on the probability of divorce even when they are exogenous to the individual. It seems unlikely that this type of exogenous displacement would signal an underlying unsuitability. Rather, it may be that some spouses realize that job losses can affect future earning capacity even when exogenous. For example, studies such as Davis and von Wachter (2011) and Couch and Placzek (2010) find that displacements lower future earnings, especially when they occur during recessions. Consequently, the displacement need not be a signal of underlying match suitability to affect expected future earnings and thus the probability of divorce.

Finally, given the negative economic and societal consequences of divorce, it would be interesting to know whether unemployment-related policies, such as unemployment benefits or retraining programs, have any effects on the probability of divorce by ameliorating the effects of displacement on the family. Research in this area would help shed light on the relative importance of gender roles versus policy intervention in marital dissolution decisions. 


\section{REFERENCES}

Amato, Paul R. 2000. "The Consequences of Divorce for Adults and Children." Journal of Marriage and Family 62 (4):1269-1287.

Arkes, Jeremy and Yu-Chu Shen. 2010. “For Better or For Worse, But How About a Recession?" NBER Working Paper 16525.

Becker, Gary S. 1974. "A Theory of Marriage" in Economics of the Family. Edited by T. W. Schultz. Chicago, IL: University of Chicago Press.

Becker, Gary S., Elisabeth M. Landes, and Robert T. Michael. 1977. "An Economic Analysis of Marital Instability." Journal of Political Economy 85(6):1141-1187.

Bertrand, Marianne, Emir Kamenica, and Jessica Pan. 2013. "Gender identity and relative income within households." Natural Bureau of Economic Research Working Paper No. 19023.

Biblarz, Timothy J. and Greg Gottainer. 2004. "Family Structure and Children's Success: A Comparison of Widowed and Divorced Single-Mother Families." Journal of Marriage and the Family 62(2):533548.

Bredemeier, Christian and Falko Juessen. 2013. "Assortative Mating and Female Labor Supply." Journal of Labor Economics 31(3):603-631.

Charles, Kerwin Kofi, and Melvin Stephens, Jr. 2004. "Job Displacement, Disability, and Divorce." Journal of Labor Economics 22(2):489-522.

Corak, Miles. 2001 "Death and Divorce: The Long-Term Consequences of Parental Loss on Adolescents." Journal of Labor Economic 19(3): 682-715.

Couch, Kenneth A. and Dana W. Placzek. 2010. "Earnings Losses of Displaced Workers Revisited." American Economic Review 100(1):572-589.

Davis, Steven J. and Till von Wachter. 2011. "Recessions and the Costs of Job Loss." Brookings Papers on Economic Activity (Fall).

Doiron, Denise and Silvia Mendolia. 2011. "The Impact of Job on Family Dissolution." Journal of Population Economics 25(1):367-398.

Farnham, Martin, Lucie Schmidt, and Purvi Sevak. 2011. "House Prices and Marital Stability." American Economic Review: Papers and Proceedings 101(3):615-619.

Guo, Guang. 1993. "Event-History Analysis for Left-Truncated Data." Sociological Methodology 23:217243.

Gruber, Jonathan. 2004. "Is Making Divorce Easier Bad for Children? The Long-Run Implications of Unilateral Divorce." Journal of Labor Economics 22(4):799-833. 
Hankins, Scott and Mark Hoekstra. 2011. "Lucky in Life, Unlucky in Love? The Effect of Random Income Shocks on Marriage and Divorce." Journal of Human Resources 46(2):403-426.

Hellerstein, Judith K. and Melinda Sandler Morrill. 2011. "Booms, Busts, and Divorce." The B.E. Journal of Economic Analysis and Policy 11(1), Article 54.

Hellerstein, Judith K., Melinda Sandler Morrill, and Ben Zou. 2013. "Business Cycles and Divorce: Evidence from Microdata." Economic Letters 188(January):68-70.

Isen, Adam and Betsey Stevenson. 2011. “Women's Education and Family Behavior: Trends in Marriage, Divorce, and Fertility" in Demography and the Economy. Edited by John B. Shoven. Chicago, IL: The University of Chicago Press.

Kane, John, Lawrence M. Spizman, James Rodgers and Rick R. Gaskins. 2010. "The Effect of the Loss of a Parent on the Future Earnings of a Minor Child." Eastern Economic Journal 36:370-390.

Lundberg, Shelly. 2012. "Personality and marital surplus." IZA Journal of Labor Economics 1:3.

Page, Marianne E. and Ann Huff Stevens. 2004 "The Economic Consequences of Absent Parents." Journal of Human Resources 39(1):80-107.

Painter, Gary and David I. Levine. 2000. "Family Structure and Youths' Outcomes: Which Correlations Are Causal?" Journal of Human Resources 35(3):524-49.

Singleton, Perry. 2012. "Insult to Injury: Disability, Earnings, and Divorce." Journal of Human Resources 47(4):972-990.

Stevenson, Betsey and Justin Wolfers. 2007. "Marriage and Divorce: Changes and Their Driving Forces." Journal of Economic Perspectives 21(2):27-52.

Tartari, Melissa. 2007. "Divorce and the Cognitive Achievement of Children." Unpublished manuscript, Yale University.

Weiss, Yoram, and Robert J. Willis. 1997. "Match Quality, New Information, and Martial Dissolution." Journal of Labor Economics 15(1, pt. 2):S293-S329.

Wooldridge, Jeffrey M. 2010. Econometric Analysis of Cross Section and Panel Data. Cambridge, MA: The MIT Press. 
Figure 1 - Annual Divorce Hazard Conditional on Marriage Duration

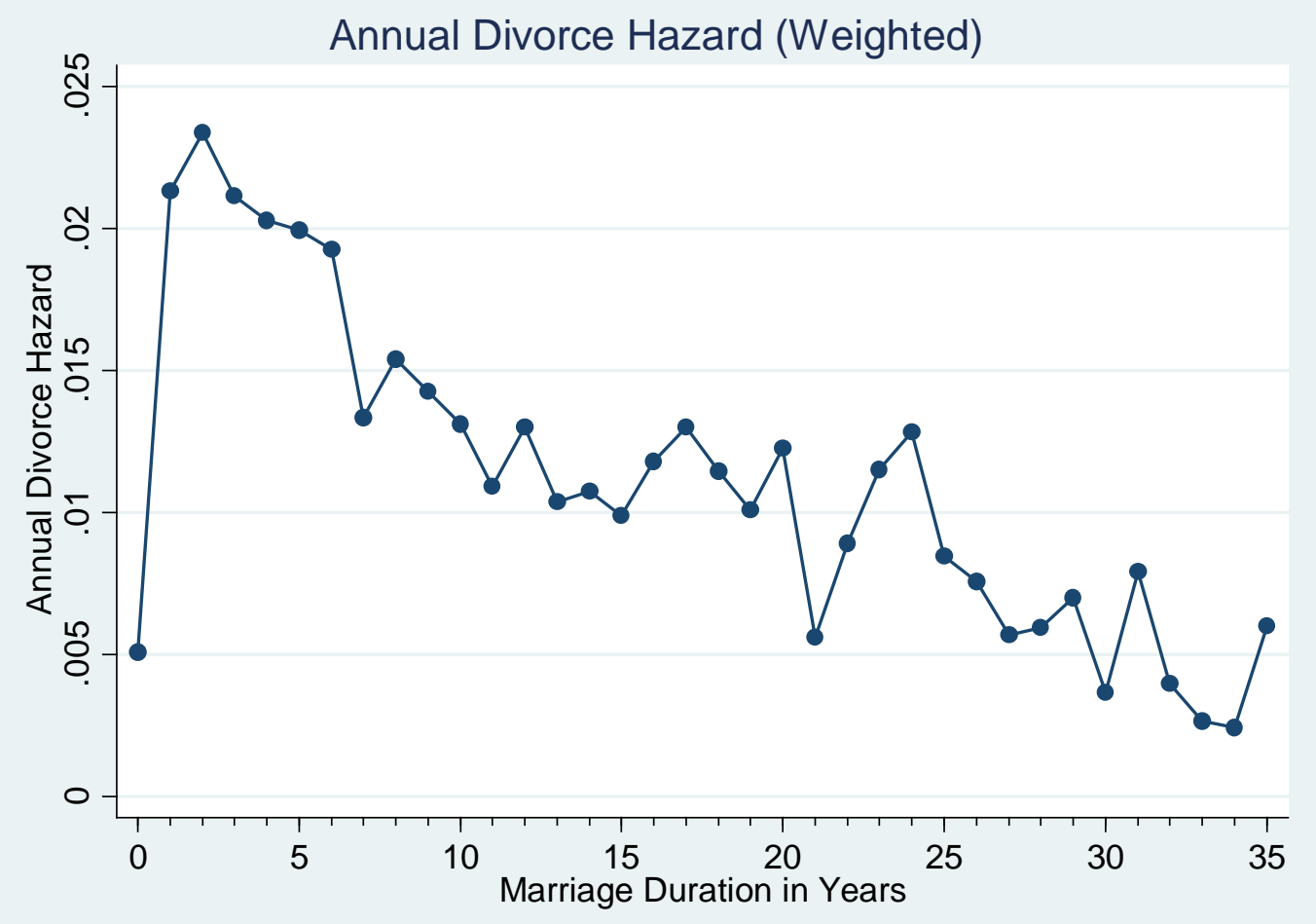


Table 1 - Means of Selected Characteristics for Married Couples in Sample (statistics are weighted; standard deviations in parentheses)

\begin{tabular}{|c|c|c|c|c|}
\hline & All Panels & 2001 & 2004 & 2008 \\
\hline \multicolumn{5}{|l|}{ Match Characteristics of Couple: } \\
\hline $\begin{array}{l}\text { Husband's age when current marriage } \\
\text { began }^{1}\end{array}$ & $\begin{array}{l}28.87 \\
(7.94)\end{array}$ & $\begin{array}{l}28.54 \\
(7.87)\end{array}$ & $\begin{array}{l}28.68 \\
(7.83)\end{array}$ & $\begin{array}{l}29.29 \\
(8.05)\end{array}$ \\
\hline $\begin{array}{l}\text { Wife's age when current marriage } \\
\text { began }^{1}\end{array}$ & $\begin{array}{l}26.77 \\
(7.56) \\
\end{array}$ & $\begin{array}{l}26.38 \\
(7.48) \\
\end{array}$ & $\begin{array}{l}26.63 \\
(7.50) \\
\end{array}$ & $\begin{array}{l}27.20 \\
(7.64) \\
\end{array}$ \\
\hline $\begin{array}{l}\text { Dummy for age difference greater } \\
\text { than } 10 \text { years between spouses }{ }^{1}\end{array}$ & $\begin{array}{l}.06 \\
(.24)\end{array}$ & $\begin{array}{l}.06 \\
(.24)\end{array}$ & $\begin{array}{l}.06 \\
(.24)\end{array}$ & $\begin{array}{l}.06 \\
(.24)\end{array}$ \\
\hline Dummy for first marriage $^{1}$ & $\begin{array}{l}.67 \\
(.47)\end{array}$ & $\begin{array}{l}.66 \\
(.47)\end{array}$ & $\begin{array}{l}.67 \\
(.47)\end{array}$ & $\begin{array}{l}.68 \\
(.47)\end{array}$ \\
\hline Dummy for same race $^{1}$ & $\begin{array}{l}.92 \\
(.27)\end{array}$ & $\begin{array}{c}.94 \\
(.24)\end{array}$ & $\begin{array}{c}.92 \\
(.27)\end{array}$ & $\begin{array}{c}.92 \\
(.28)\end{array}$ \\
\hline Dummy for both white, non-hispanic $^{1}$ & $\begin{array}{l}.73 \\
(.45) \\
\end{array}$ & $\begin{array}{c}.76 \\
(.43) \\
\end{array}$ & $\begin{array}{c}.72 \\
(.45) \\
\end{array}$ & $\begin{array}{l}.70 \\
(.46) \\
\end{array}$ \\
\hline Dummy for both black, non-hispanic $^{1}$ & $\begin{array}{l}.06 \\
(.24)\end{array}$ & $\begin{array}{l}.06 \\
(.24)\end{array}$ & $\begin{array}{l}.06 \\
(.24)\end{array}$ & $\begin{array}{l}.06 \\
(.23)\end{array}$ \\
\hline Dummy for same education level: & $\begin{array}{l}.60 \\
(.49) \\
\end{array}$ & $\begin{array}{l}.60 \\
(.49) \\
\end{array}$ & $\begin{array}{l}.59 \\
(.49) \\
\end{array}$ & $\begin{array}{l}.60 \\
(.49) \\
\end{array}$ \\
\hline Both high school grads or less & $\begin{array}{c}.21 \\
(.41)\end{array}$ & $\begin{array}{l}.26 \\
(.44)\end{array}$ & $\begin{array}{l}.19 \\
(.39)\end{array}$ & $\begin{array}{l}.19 \\
(.39)\end{array}$ \\
\hline Both some college & $\begin{array}{l}.16 \\
(.36)\end{array}$ & $\begin{array}{l}.14 \\
(.35)\end{array}$ & $\begin{array}{l}18 \\
.18 \\
(.38)\end{array}$ & $\begin{array}{l}.16 \\
(.37)\end{array}$ \\
\hline Both college grads. & $\begin{array}{l}.23 \\
(.42)\end{array}$ & $\begin{array}{c}.21 \\
(.41)\end{array}$ & $\begin{array}{l}.22 \\
(.42)\end{array}$ & $\begin{array}{l}.25 \\
(.44)\end{array}$ \\
\hline \multicolumn{5}{|l|}{ Marital Investments: } \\
\hline Marriage duration & $\begin{array}{c}17.12 \\
(11.22)\end{array}$ & $\begin{array}{c}16.55 \\
(11.08)\end{array}$ & $\begin{array}{c}17.13 \\
(11.04)\end{array}$ & $\begin{array}{c}17.55 \\
(11.41)\end{array}$ \\
\hline Dummy for any children & $\begin{array}{l}.67 \\
(.47)\end{array}$ & $\begin{array}{l}.67 \\
(.47)\end{array}$ & $\begin{array}{l}.68 \\
(.47)\end{array}$ & $\begin{array}{l}.65 \\
(.48)\end{array}$ \\
\hline $\begin{array}{l}\text { Total number of children in household, } \\
\text { if any }\end{array}$ & $\begin{array}{c}2.01 \\
(1.02)\end{array}$ & $\begin{array}{c}1.99 \\
(1.00)\end{array}$ & $\begin{array}{c}2.03 \\
(1.02)\end{array}$ & $\begin{array}{c}2.01 \\
(1.03)\end{array}$ \\
\hline $\begin{array}{l}\text { Dummy for either spouse previously } \\
\text { divorced }^{1}\end{array}$ & $\begin{array}{l}.32 \\
(.47)\end{array}$ & $\begin{array}{l}.33 \\
(.47)\end{array}$ & $\begin{array}{l}.32 \\
(.47)\end{array}$ & $\begin{array}{l}.31 \\
(.46)\end{array}$ \\
\hline $\begin{array}{l}\text { Dummy for couples with any step- } \\
\text { children in household }\end{array}$ & $\begin{array}{l}.08 \\
(.27)\end{array}$ & $\begin{array}{l}.07 \\
(.26)\end{array}$ & $\begin{array}{c}.09 \\
(.29)\end{array}$ & $\begin{array}{c}.08 \\
(.28)\end{array}$ \\
\hline Total number of step-children, if any & $\begin{array}{l}1.50 \\
(.79)\end{array}$ & $\begin{array}{l}1.51 \\
(.83)\end{array}$ & $\begin{array}{l}1.50 \\
(.78)\end{array}$ & $\begin{array}{l}1.48 \\
(.75)\end{array}$ \\
\hline Dummy for owning home & $\begin{array}{c}.84 \\
(.37)\end{array}$ & $\begin{array}{c}.84 \\
(.37)\end{array}$ & $\begin{array}{c}.85 \\
(.36)\end{array}$ & $\begin{array}{c}.83 \\
(.38)\end{array}$ \\
\hline Dummy for any investment income & $\begin{array}{c}.69 \\
(.46)\end{array}$ & $\begin{array}{c}.69 \\
(.46)\end{array}$ & $\begin{array}{c}.71 \\
(.45)\end{array}$ & $\begin{array}{l}.69 \\
(.46)\end{array}$ \\
\hline $\begin{array}{l}\text { Real Monthly Investment income } \\
\text { (2001 Dollars), if any }\end{array}$ & $\begin{array}{c}99.29 \\
(361.87)\end{array}$ & $\begin{array}{c}116.80 \\
(437.30) \\
\end{array}$ & $\begin{array}{c}102.51 \\
(327.97) \\
\end{array}$ & $\begin{array}{c}82.87 \\
(309.40) \\
\end{array}$ \\
\hline
\end{tabular}




\begin{tabular}{|c|c|c|c|c|}
\hline & All Panels & 2001 & 2004 & 2008 \\
\hline \multicolumn{5}{|l|}{ Labor Market and Divorce Characteristics: } \\
\hline Dummy for divorce observed $^{1}$ & $\begin{array}{c}.041 \\
(.198)\end{array}$ & $\begin{array}{c}.041 \\
(.198)\end{array}$ & $\begin{array}{c}.039 \\
(.193)\end{array}$ & $\begin{array}{c}.042 \\
(.201)\end{array}$ \\
\hline Dummy for displacement observed $^{1}$ & $\begin{array}{c}.062 \\
(.241)\end{array}$ & $\begin{array}{l}.067 \\
(.250)\end{array}$ & $\begin{array}{c}.045 \\
(.208)\end{array}$ & $\begin{array}{c}.068 \\
(.251)\end{array}$ \\
\hline $\begin{array}{l}\text { Dummy for both displacement and } \\
\text { divorce observed }^{1}\end{array}$ & $\begin{array}{l}.003 \\
(.053)\end{array}$ & $\begin{array}{l}.003 \\
(.057)\end{array}$ & $\begin{array}{l}.002 \\
(.047)\end{array}$ & $\begin{array}{l}.003 \\
(.053)\end{array}$ \\
\hline $\begin{array}{l}\text { Dummy for divorce observed if no } \\
\text { displacement }^{1}\end{array}$ & $\begin{array}{l}.040 \\
(.197)\end{array}$ & $\begin{array}{l}.040 \\
(.196)\end{array}$ & $\begin{array}{l}.038 \\
(.192)\end{array}$ & $\begin{array}{l}.042 \\
(.201)\end{array}$ \\
\hline $\begin{array}{l}\text { Dummy for divorce observed if } \\
\text { displacement }^{1}\end{array}$ & $\begin{array}{c}.046 \\
(.209)\end{array}$ & $\begin{array}{c}.049 \\
(.217)\end{array}$ & $\begin{array}{c}.049 \\
(.216)\end{array}$ & $\begin{array}{c}.041 \\
(.198)\end{array}$ \\
\hline $\begin{array}{l}\text { Dummy for husband displaced if any } \\
\text { displacement }^{1}\end{array}$ & $\begin{array}{c}.588 \\
(.492)\end{array}$ & $\begin{array}{c}.586 \\
(.493)\end{array}$ & $\begin{array}{c}.550 \\
(.497)\end{array}$ & $\begin{array}{c}.617 \\
(.486)\end{array}$ \\
\hline $\begin{array}{l}\text { Dummy for both spouses displaced if } \\
\text { any displacement }{ }^{1}\end{array}$ & $\begin{array}{c}.055 \\
(.228)\end{array}$ & $\begin{array}{c}.055 \\
(.229)\end{array}$ & $\begin{array}{c}.059 \\
(.235)\end{array}$ & $\begin{array}{c}.053 \\
(.224)\end{array}$ \\
\hline $\begin{array}{l}\text { Length of nonemployment in months } \\
\text { following displacement }^{2}\end{array}$ & $\begin{array}{c}8.60 \\
(8.75)\end{array}$ & $\begin{array}{c}7.53 \\
(7.62)\end{array}$ & $\begin{array}{c}7.34 \\
(8.01)\end{array}$ & $\begin{array}{l}10.09 \\
(9.70)\end{array}$ \\
\hline $\begin{array}{l}\text { Length of unemployment spell in } \\
\text { months following displacement }{ }^{3}\end{array}$ & $\begin{array}{c}6.74 \\
(6.99)\end{array}$ & $\begin{array}{c}5.65 \\
(5.33)\end{array}$ & $\begin{array}{c}4.65 \\
(4.69)\end{array}$ & $\begin{array}{c}8.37 \\
(8.36)\end{array}$ \\
\hline $\begin{array}{l}\text { Length of out-of-labor force spell in } \\
\text { months following displacement }{ }^{4}\end{array}$ & $\begin{array}{c}12.09 \\
(10.47)\end{array}$ & $\begin{array}{l}10.91 \\
(9.68)\end{array}$ & $\begin{array}{l}10.94 \\
(9.88)\end{array}$ & $\begin{array}{c}13.97 \\
(11.27)\end{array}$ \\
\hline $\begin{array}{l}\text { Proportion of earnings lost when } \\
\text { displaced }^{1}\end{array}$ & $\begin{array}{c}.530 \\
(.326)\end{array}$ & $\begin{array}{l}.521 \\
(.319)\end{array}$ & $\begin{array}{c}.516 \\
(.338)\end{array}$ & $\begin{array}{c}.543 \\
(.325)\end{array}$ \\
\hline $\begin{array}{l}\text { Dummy for other spouse employed if } \\
\text { any displacement }\end{array}$ & $\begin{array}{c}.705 \\
(.456) \\
\end{array}$ & $\begin{array}{l}.722 \\
(.448)\end{array}$ & $\begin{array}{c}.692 \\
(.462)\end{array}$ & $\begin{array}{c}.697 \\
(.459)\end{array}$ \\
\hline $\begin{array}{l}\text { Real Monthly Family Earnings ( } 2001 \\
\text { Dollars) - Including zeros }\end{array}$ & $\begin{array}{l}5,732.71 \\
(5266.31)\end{array}$ & $\begin{array}{l}5,680.19 \\
(5157.30)\end{array}$ & $\begin{array}{l}5,930.95 \\
(5635.98)\end{array}$ & $\begin{array}{l}5,655.07 \\
(5116.57)\end{array}$ \\
\hline $\begin{array}{l}\text { Real Monthly Husband Earnings (2001 } \\
\text { Dollars) - Including zeros }\end{array}$ & $\begin{array}{c}3,703.03 \\
(4392.92)\end{array}$ & $\begin{array}{c}3,688.61 \\
(4311.10)\end{array}$ & $\begin{array}{c}3,866.93 \\
(4840.62)\end{array}$ & $\begin{array}{l}3,615.24 \\
(4164.49)\end{array}$ \\
\hline $\begin{array}{l}\text { Real Monthly Wife Earnings (2001 } \\
\text { Dollars) - Including zeros }\end{array}$ & $\begin{array}{l}1,750.67 \\
(2436.79)\end{array}$ & $\begin{array}{l}1,702.26 \\
(2324.51)\end{array}$ & $\begin{array}{l}1,759.10 \\
(2477.44)\end{array}$ & $\begin{array}{l}1,784.94 \\
(2499.68)\end{array}$ \\
\hline $\begin{array}{l}\text { Dummy for living in a metropolitan } \\
\text { area }\end{array}$ & $\begin{array}{l}.78 \\
(.41)\end{array}$ & $\begin{array}{l}.76 \\
(.43)\end{array}$ & $\begin{array}{c}.81 \\
(.39)\end{array}$ & $\begin{array}{l}.79 \\
(.41)\end{array}$ \\
\hline $\begin{array}{l}\text { Average state unemployment rate for } \\
\text { prior } 3 \text { months }\end{array}$ & $\begin{array}{r}6.48 \\
(2.25) \\
\end{array}$ & $\begin{array}{c}5.21 \\
(1.15) \\
\end{array}$ & $\begin{array}{l}5.11 \\
(.97) \\
\end{array}$ & $\begin{array}{r}8.30 \\
(2.19) \\
\end{array}$ \\
\hline No. of months observed in the SIPP & $\begin{array}{c}31.17 \\
(12.48) \\
\end{array}$ & $\begin{array}{l}30.12 \\
(9.76) \\
\end{array}$ & $\begin{array}{c}30.72 \\
(13.13) \\
\end{array}$ & $\begin{array}{c}32.29 \\
(13.79) \\
\end{array}$ \\
\hline No. of monthly observations & 993,503 & 308,225 & 268,389 & 416,889 \\
\hline No. of couples & 31,878 & 10,232 & 8,737 & 12,909 \\
\hline
\end{tabular}

${ }^{1}$ Averaged across couples only, not across monthly observations.

${ }^{2}$ Nonemployment includes periods spent in unemployment or out-of-the labor force.

${ }^{3}$ The spell was defined as unemployment if the individual was unemployed for at least half of the nonemployment spell.

${ }^{4}$ The spell was defined as out-of-the-labor force if the individual was unemployed for less than half of the nonemployment spell. 
Table 2. Discrete-time hazard model (probit) of divorce - Base models ignoring displacement (standard errors are clustered by couple)

\begin{tabular}{|c|c|c|}
\hline & $\begin{array}{c}1) \\
\text { Base Model (no } \\
\text { displacement } \\
\text { variables, no } \\
\text { earnings) } \\
\end{array}$ & $\begin{array}{c}\text { (2) } \\
\text { Base Model (no } \\
\text { displacement } \\
\text { variables, with } \\
\text { earnings) } \\
\end{array}$ \\
\hline \multicolumn{3}{|l|}{ Marriage Duration spline: } \\
\hline $3-5$ years & $\begin{array}{l}0.0919 * \\
(0.0381)\end{array}$ & $\begin{array}{l}0.0912 * \\
(0.0381)\end{array}$ \\
\hline $5-7$ years & $\begin{array}{l}0.106^{* *} \\
(0.0402) \\
\end{array}$ & $\begin{array}{l}0.105^{* *} \\
(0.0402) \\
\end{array}$ \\
\hline $7-10$ years & $\begin{array}{c}0.0668 \\
(0.0397) \\
\end{array}$ & $\begin{array}{c}0.0663 \\
(0.0397) \\
\end{array}$ \\
\hline $10-15$ years & $\begin{array}{l}0.0972 * \\
(0.0394) \\
\end{array}$ & $\begin{array}{l}0.0976 * \\
(0.0393) \\
\end{array}$ \\
\hline $15-20$ years & $\begin{array}{l}0.153^{* *} \\
(0.0429) \\
\end{array}$ & $\begin{array}{l}0.153^{* *} \\
(0.0429) \\
\end{array}$ \\
\hline $20-25$ years & $\begin{array}{c}0.0527 \\
(0.0467)\end{array}$ & $\begin{array}{c}0.0524 \\
(0.0467)\end{array}$ \\
\hline $25-30$ years & $\begin{array}{l}-0.104^{*} \\
(0.0498) \\
\end{array}$ & $\begin{array}{c}-0.105^{*} \\
(0.0499) \\
\end{array}$ \\
\hline $30-50$ years & $\begin{array}{c}-0.468^{* *} \\
(0.0531) \\
\end{array}$ & $\begin{array}{c}-0.465^{* *} \\
(0.0533) \\
\end{array}$ \\
\hline priordiv-Dummy for any prior divorce & $\begin{array}{c}-0.0354 \\
(0.0268)\end{array}$ & $\begin{array}{c}-0.0355 \\
(0.0268) \\
\end{array}$ \\
\hline totalkids - No. of children in household & $\begin{array}{c}-0.151^{* *} \\
(0.0143) \\
\end{array}$ & $\begin{array}{c}-0.149 * * \\
(0.0144) \\
\end{array}$ \\
\hline totalkids0_5 - No. of children, age 0 to 5 , in household & $\begin{array}{l}0.0446 * \\
(0.0196) \\
\end{array}$ & $\begin{array}{l}0.0486^{*} \\
(0.0196) \\
\end{array}$ \\
\hline stepkids - No. of step-children in household & $\begin{array}{l}0.564^{* *} \\
(0.0333) \\
\end{array}$ & $\begin{array}{l}0.562^{* *} \\
(0.0333) \\
\end{array}$ \\
\hline stepkids $^{2}$ & $\begin{array}{c}-0.0519 * * \\
(0.00818)\end{array}$ & $\begin{array}{c}-0.0517^{* *} \\
(0.00818)\end{array}$ \\
\hline ownhome - Dummy for own home & $\begin{array}{l}-0.180^{* *} \\
(0.0222) \\
\end{array}$ & $\begin{array}{l}-0.186^{* *} \\
(0.0227) \\
\end{array}$ \\
\hline assetinc -Total dividend/interest income (real \$, per 1000) & $\begin{array}{c}-0.125 \\
(0.0811) \\
\end{array}$ & $\begin{array}{c}-0.129 \\
(0.0821) \\
\end{array}$ \\
\hline assetinc $^{2}$ & $\begin{array}{c}0.00756 \\
(0.00517) \\
\end{array}$ & $\begin{array}{c}0.00781 \\
(0.00522) \\
\end{array}$ \\
\hline $\begin{array}{l}\text { agediff } 10 \text { - Dummy for age difference between spouses greater than } \\
10 \text { years }\end{array}$ & $\begin{array}{c}0.0482 \\
(0.0329) \\
\end{array}$ & $\begin{array}{c}0.0484 \\
(0.0329) \\
\end{array}$ \\
\hline agemarr_w - Age at marriage for wife & \begin{tabular}{r|r|}
$-0.0159 * *$ \\
$(0.00182)$ \\
\end{tabular} & $\begin{array}{l}-0.0159 * * \\
(0.00183) \\
\end{array}$ \\
\hline earn_h - -Husband's real earnings (per $\$ 1,000$ ) & & $\begin{array}{l}-0.00650 \\
(0.00412)\end{array}$ \\
\hline earn_h $h^{2}$ & & $\begin{array}{c}0.000259^{* *} \\
(6.59 \mathrm{e}-05)\end{array}$ \\
\hline earn_w - Wife's real earnings (per $\$ 1,000$ ) & & $0.0218^{*}$ \\
\hline
\end{tabular}


(0.00916)

\begin{tabular}{lcc}
\hline earn_w $w^{2}$ & & -0.00114 \\
earn_h*earn_w & & $(0.000670)$ \\
\hline metro - Dummy for residing in metropolitan area & & $-1.89 \mathrm{e}-05$ \\
& & $(0.000772)$ \\
\hline unemp_rate - Avg. state unemployment rate for prior 3 months & 0.00635 & 0.00516 \\
& $(0.0239)$ & $(0.0239)$ \\
\hline constant & 0.0132 & 0.0134 \\
& $(0.0167)$ & $(0.0167)$ \\
\hline & $-3.355^{* *}$ & $-3.353^{* *}$ \\
Full education interactions between spouses & $(0.296)$ & $(0.296)$ \\
Full racial interactions between spouses & & \\
State dummies & Yes & Yes \\
Month-year dummies & Yes & Yes \\
Linear state time trend & Yes & Yes \\
& Yes & Yes \\
No. of couple-month observations & Yes & \\
No. of couples & & 992,539 \\
Pseudo R-squared & 992,539 & 31,850 \\
\end{tabular}

Robust standard errors in parentheses

** $p<0.01, * p<0.05$ 
Table 3. Discrete-time hazard model (probit) of divorce - Includes displacement variables (includes base model variables and controls for state effects, month-year effects, and linear state-time trend; standard errors are clustered by couple)

\begin{tabular}{lccc}
\hline & $\begin{array}{c}(1) \\
\text { Displacement - } \\
\text { one spouse, no } \\
\text { earnings }\end{array}$ & $\begin{array}{c}(2) \\
\text { Displacement - } \\
\text { one spouse, } \\
\text { with earnings }\end{array}$ & $\begin{array}{c}\text { Displacement - } \\
\text { both spouses }\end{array}$ \\
\hline displaced & $0.0972^{* *}$ & $0.0982^{* *}$ & $0.101^{* *}$ \\
& $(0.0368)$ & $(0.0371)$ & $(0.0376)$ \\
displaced*displaced_both & & & -0.0742 \\
& & & $(0.173)$ \\
Includes earnings variables & No & Yes & No \\
No. of couple-month observations & & & 992,539 \\
No. of couples & 992,539 & 992,539 & 31,850 \\
Pseudo R-squared & 31,850 & 31,850 & 0.1086 \\
\hline
\end{tabular}

Robust standard errors in parentheses

$$
\text { ** } \mathrm{p}<0.01, * \mathrm{p}<0.05
$$


Table 4. Discrete-time hazard model (probit) of divorce - displacement variable interacted with sex of laid-off spouse and the unemployment rate (includes base model variables and controls for state effects, month-year effects, and linear state-time trend; standard errors are clustered by couple)

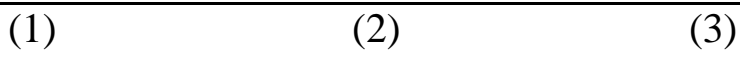

No spouse or $\quad$ Spouse Spouse and unemployment rate interactions unemploy. rate interactions interactions

displaced

$0.105 * *$

$(0.0391)$

displaced*wife

0.0355

0.0821

(0.0638)

displaced*wife*unemp_rate

$-0.00667$

$(0.0242)$

displaced*husband

$0.150 * *$

$0.307 *$

(0.0480)

displaced*husband*unemp_rate

$-0.0219$

(0.0198)

No. of couple-month observations

970,011

970,011

970,011

No. of couples

31,196

31,196

31,196

Pseudo R-squared

0.1092

0.1093

0.1093

Robust standard errors in parentheses

$$
\text { ** } \mathrm{p}<0.01,{ }^{*} \mathrm{p}<0.05
$$


Table 5. Discrete-time hazard model (probit) of divorce - displacement variable interacted with proportion of lost earnings and sex of laid-off spouse (includes base model variables and controls for state effects, month-year effects, and linear state-time trend; standard errors are clustered by couple)

(1)

Displacement only
(2)

Displacement \& proportion of lost earnings
(3)

Displacement \& proportion of lost earnings with spouse interactions

displaced

$0.105 * *$

$(0.0391)$
0.132

(0.0749)

$-0.0534$

$(0.122)$

displaced*wife

0.0989

displaced ${ }^{*}$ wife $*$ lostearn

$-0.183$

displaced*husband

$0.233^{*}$

displaced *husband*lostearn

No. of couple-month observations

970,011

31,196

970,011

970,011

No. of couples

0.1092

31,196

31,196

Pseudo R-squared

Robust standard errors in parentheses

** $\mathrm{p}<0.01, * \mathrm{p}<0.05$ 
Table 6. Discrete-time hazard model (probit) of divorce - displacement variable and proportion of lost earnings by group and sex of laid-off spouse (includes base model variables, weights and controls for state effects, month-year effects, and linear state-time trend; standard errors are clustered by couple)

(1) (2) (3)

Displacement Proportion of Proportion of only lost earnings by lost earnings by group group with spouse interactions

\begin{tabular}{|c|c|c|c|}
\hline displaced & $\begin{array}{l}0.105 * * \\
(0.0391)\end{array}$ & & \\
\hline displaced ${ }^{*}$ minor loss (0 to 0.33 ] & & $\begin{array}{c}0.0917 \\
(0.0617)\end{array}$ & \\
\hline displaced*minor loss*wife & & & $\begin{array}{c}0.0444 \\
(0.0798)\end{array}$ \\
\hline displaced*minor loss*husband & & & $\begin{array}{c}0.169 \\
(0.0953)\end{array}$ \\
\hline displaced*equal loss (0.33 to 0.66] & & $\begin{array}{c}0.116 \\
(0.0787)\end{array}$ & \\
\hline displaced*equal loss*wife & & & $\begin{array}{l}-0.102 \\
(0.165)\end{array}$ \\
\hline displaced*equal loss*husband & & & $\begin{array}{c}0.204^{*} \\
(0.0895)\end{array}$ \\
\hline displaced*major loss (0.66 to 0.99] & & $\begin{array}{c}0.0800 \\
(0.0973)\end{array}$ & \\
\hline displaced $^{*}$ major loss*wife & & & $\begin{array}{c}0.298 \\
(0.248)\end{array}$ \\
\hline displaced*major loss*husband & & & $\begin{array}{l}0.0409 \\
(0.104)\end{array}$ \\
\hline displaced ${ }^{*}$ complete loss [1.00] & & $\begin{array}{c}0.136 \\
(0.0775)\end{array}$ & \\
\hline displaced*complete loss*wife & & & $\begin{array}{l}0.0589 \\
(0.148)\end{array}$ \\
\hline displaced*complete loss*husband & & & $\begin{array}{c}0.158 \\
(0.0900)\end{array}$ \\
\hline No. of couple-month observations & 970,011 & 970,011 & 970,011 \\
\hline No. of couples & 31,196 & 31,196 & 31,196 \\
\hline Pseudo R-squared & 0.1092 & 0.1092 & 0.1095 \\
\hline
\end{tabular}

Robust standard errors in parentheses

** $\mathrm{p}<0.01, * \mathrm{p}<0.05$ 
Table 7. Discrete-time hazard model (probit) of divorce - displacement variable, employment status of spouse and unemployment rate interactions (includes base model variables and controls for state effects, month-year effects, and linear state-time trend; standard errors are clustered by couple)

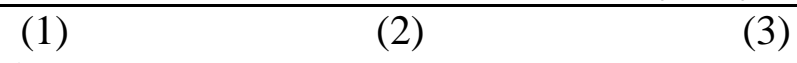

Displacement

Spouse's only employment status

Spouse's employment

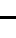

$\begin{array}{ccc} & 0.105^{* *} & 0.0244 \\ \text { displaced } & (0.0391) & (0.0765)\end{array}$

displaced*spouse_employed

0.105

(0.0872)

displaced $^{*}$ wife

0.000360

(0.150)

displaced ${ }^{*}$ wife

0.0406

*spouse_employed

displaced*husband

0.0317

(0.0885)

displaced *husband

0.167

*spouse_employed

(0.105)

No. of couple-month

970,011

970,011

970,011

observations

No. of couples

31,196

31,196

31,196

Pseudo R-squared

0.1092

0.1092

0.1094

Robust standard errors in parentheses

$$
\text { ** } \mathrm{p}<0.01,{ }^{*} \mathrm{p}<0.05
$$


Table 8. Discrete-time hazard model (probit) of divorce - displacement variable, earnings of spouse and unemployment rate interactions (includes base model variables and controls for state effects, month-year effects, and linear state-time trend; standard errors are clustered by couple)

(1) (2) (3)

Displacement Spouse's earnings Spouse's earnings only by sex

$\begin{array}{lcc}\text { displaced } & 0.105^{* *} & 0.0607 \\ & (0.0391) & (0.0441) \\ \text { displaced*spouse_earn } & & 0.0195^{*} \\ & & (0.00900)\end{array}$

displaced $^{*}$ wife

$-0.0287$

displaced $^{*}$ wife

0.0170

*spouse_earn

displaced*husband

0.0856

displaced*husband

$0.0440 * *$

*spouse_earn

(0.0144)

No. of couple-month observations

970,011

970,011

970,011

No. of couples

31,196

31,196

31,196

Pseudo R-squared

0.1092

0.1093

0.1102

Robust standard errors in parentheses

$$
\text { ** } \mathrm{p}<0.01, * \mathrm{p}<0.05
$$


Table 9. Discrete-time hazard model (probit) of divorce - displacement variable and duration of nonemployment, unemployment, and out-of-labor force (OLF) spells (includes base model variables and controls for state effects, month-year effects, and linear state-time trend; standard errors are clustered by couple)

\section{(1)}

Duration of nonemployment spell

$$
0.0425
$$

(0.0518)

0.00978

$(0.00521)$
displaced*OLF_spell

displaced* unemp_spell

displaced $^{*}$ wife

displaced*wife*OLF_spell

displaced*wife*unemp_spell*

displaced*husband

displaced*husband*OLF_spell

displaced*husband*unemp_spell*

No. of couple-month observations

No. of couples

Pseudo R-squared
(2)

Duration of unempl. Duration of unempl. and OLF spells and OLF spells by

(3)
sex
0.00930

(0.00596)

0.0108

$(0.00721)$
0.0405

$(0.0527)$

\begin{tabular}{|c|c|c|c|}
\hline displaced & $\begin{array}{c}0.0425 \\
(0.0518)\end{array}$ & $\begin{array}{c}0.0405 \\
(0.0527)\end{array}$ & \\
\hline displaced*nonemp_spell & $\begin{array}{c}0.00978 \\
(0.00521)\end{array}$ & & \\
\hline displaced* OLF_spell & & $\begin{array}{c}0.00930 \\
(0.00596)\end{array}$ & \\
\hline displaced $^{*}$ unemp_spell & & $\begin{array}{c}0.0108 \\
(0.00721)\end{array}$ & \\
\hline displaced*wife & & & $\begin{array}{c}0.0635 \\
(0.0797)\end{array}$ \\
\hline displaced*wife*OLF_spell & & & $\begin{array}{l}-0.00300 \\
(0.00845)\end{array}$ \\
\hline displaced $^{*}$ wife ${ }^{*}$ unemp_spell* & & & $\begin{array}{c}-0.00613 \\
(0.0124)\end{array}$ \\
\hline displaced*husband & & & $\begin{array}{c}0.0327 \\
(0.0679)\end{array}$ \\
\hline displaced*husband*OLF_spell & & & $\begin{array}{c}0.0198 * \\
(0.00775)\end{array}$ \\
\hline displaced*husband*unemp_spell* & & & $\begin{array}{c}0.0182 * \\
(0.00879)\end{array}$ \\
\hline No. of couple-month observations & 970,011 & 970,011 & 970,011 \\
\hline No. of couples & 31,196 & 31,196 & 31,196 \\
\hline Pseudo R-squared & 0.1093 & 0.1093 & 0.1097 \\
\hline
\end{tabular}

Robust standard errors in parentheses

** $\mathrm{p}<0.01,{ }^{*} \mathrm{p}<0.05$ 
Table 10. Discrete-time hazard model (probit) of divorce - displacement due to "employer bankrupt" or "employer sold firm" only, with employment status and earnings of non-laid-off spouse (includes base model variables and controls for state effects, month-year effects, and linear state-time trend; standard errors are clustered by couple)

\begin{tabular}{|c|c|c|c|}
\hline & $\begin{array}{c}(1) \\
\text { Displacement } \\
\text { only }\end{array}$ & $\begin{array}{c}(2) \\
\text { Spouse interactions }\end{array}$ & $\begin{array}{c}\text { (3) } \\
\text { Wife’s earnings }\end{array}$ \\
\hline displaced & $\begin{array}{l}0.0347 \\
(0.125)\end{array}$ & & \\
\hline displaced $^{*}$ wife & & $\begin{array}{l}-0.300 \\
(0.286)\end{array}$ & $\begin{array}{l}-0.300 \\
(0.286)\end{array}$ \\
\hline displaced*husband & & $\begin{array}{c}0.185 \\
(0.146)\end{array}$ & $\begin{array}{l}-0.279 \\
(0.219)\end{array}$ \\
\hline $\begin{array}{l}\text { displaced*spouse_earn } \\
\text { *husband }\end{array}$ & & & $\begin{array}{l}0.168 * * \\
(0.0509)\end{array}$ \\
\hline $\begin{array}{l}\text { No. of couple-month observations } \\
\text { No. of couples } \\
\text { Pseudo R-squared }\end{array}$ & $\begin{array}{c}915,883 \\
29,628 \\
0.1098\end{array}$ & $\begin{array}{c}915,883 \\
29,628 \\
0.1100\end{array}$ & $\begin{array}{c}915,883 \\
29,628 \\
0.1103\end{array}$ \\
\hline
\end{tabular}

Robust standard errors in parentheses

$$
\text { ** } \mathrm{p}<0.01,{ }^{*} \mathrm{p}<0.05
$$


Table 11. Discrete-time hazard model (probit) of divorce controlling for random effects - displacement variable and duration of husband's unemployment or out-of-labor-force (OLF) spells (includes base model variables, controls for state effects and month-year effects)

(1) (2)

Displacement only
Spouse interactions
(3)

Duration of husband's unemploy. and OLF spells

\begin{tabular}{ll}
\hline displaced & $0.2186^{*}$ \\
$(0.0981)$
\end{tabular}

displaced $^{*}$ wife

0.1021

.1047

(0.1531)

(.1520)

displaced*husband

0.3031*

.0259

(0.1269)

displaced*husband*OLF_spell

$.0524 * *$

(.0192)

displaced*husband*unemp_spell

.0467*

(.0216)

\begin{tabular}{lccc}
\hline $\ln \left(\sigma_{\mu}^{2}\right)$ & 1.401 & 1.445 & 1.412 \\
& $(0.039)$ & $(0.037)$ & $(0.039)$ \\
\hline$\sigma_{\mu}$ & 2.022 & 2.060 & 2.025 \\
& $(0.039)$ & $(0.039)$ & $(0.040)$ \\
rho & $0.804^{1}$ & $0.809^{1}$ & $0.804^{1}$ \\
& $(0.006)$ & $(0.006)$ & $(0.006)$ \\
\hline No. of couple-month obs. & 970,959 & 970,959 & 970,959 \\
No. of couples & 31,223 & 31,223 & 31,223 \\
\hline Notes: ${ }^{* *} \mathrm{p}<0.01,{ }^{*} \mathrm{p}<0.05,{ }^{1}$ Likelihood-ratio test of rho=0, Probability (rho $>$ = chibar2) $=0.000$
\end{tabular}


Table 12. Discrete-time hazard model (probit) of divorce controlling for random effects - displacement variable, earnings of non-laid-off spouse and proportion of lost earnings (includes base model variables, controls for state effects and month-year effects)

\begin{tabular}{|c|c|c|c|}
\hline & $\begin{array}{c}(1) \\
\text { Displacement } \\
\text { only }\end{array}$ & $\begin{array}{c}(2) \\
\text { Proportion of lost } \\
\text { earnings by group } \\
\text { with spouse } \\
\text { interactions }\end{array}$ & $\begin{array}{c}(3) \\
\text { Non-displaced } \\
\text { spouse’s } \\
\text { earnings by sex }\end{array}$ \\
\hline displaced & $\begin{array}{l}0.2186 * \\
(0.0981)\end{array}$ & & $\begin{array}{c}0.0554 \\
(0.1194)\end{array}$ \\
\hline $\begin{array}{l}\text { Proportion of Earnings Lost } \\
\text { displaced*minor loss* } \\
\text { wife } \\
\text { displaced*minor loss* } \\
\text { husband } \\
\text { displaced*equal loss* } \\
\text { wife } \\
\text { displaced*equal loss* } \\
\text { husband } \\
\text { displaced*major loss* } \\
\text { wife } \\
\text { displaced*major loss* } \\
\text { husband } \\
\text { displaced*complete loss* } \\
\text { wife } \\
\text { displaced*complete loss* } \\
\text { husband }\end{array}$ & & $\begin{array}{c}0.1739 \\
(0.1847) \\
0.4414 \\
(0.2353) \\
-0.2363 \\
(0.3842) \\
0.4399 \\
(0.2424) \\
0.5146 \\
(0.5757) \\
0.0214 \\
(0.2738) \\
-0.0783 \\
(0.4533) \\
0.2262 \\
(0.2440)\end{array}$ & \\
\hline $\begin{array}{l}\text { Spouse's earnings } \\
\text { displaced*spouse_earn } \\
\text { *wife } \\
\text { displaced*spouse_earn } \\
\text { *husband }\end{array}$ & & & $\begin{array}{c}0.0328 \\
(0.0289) \\
0.1121^{* *} \\
(0.0431)\end{array}$ \\
\hline $\ln \left(\sigma_{\mu}^{2}\right)$ & $\begin{array}{c}1.401 \\
(0.039)\end{array}$ & $\begin{array}{c}1.383 \\
(0.040)\end{array}$ & $\begin{array}{c}1.421 \\
(0.037)\end{array}$ \\
\hline rho & $\begin{array}{c}2.022 \\
(0.039) \\
0.804^{1} \\
(0.006)\end{array}$ & $\begin{array}{c}1.997 \\
(0.038) \\
0.800^{1} \\
(0.006)\end{array}$ & $\begin{array}{c}2.035 \\
(0.037) \\
0.806^{1} \\
(0.006)\end{array}$ \\
\hline $\begin{array}{l}\text { No. of couple-month obs. } \\
\text { No. of couples }\end{array}$ & $\begin{array}{c}970,959 \\
31,223\end{array}$ & $\begin{array}{c}970,959 \\
31,223\end{array}$ & $\begin{array}{c}970,959 \\
31,223\end{array}$ \\
\hline
\end{tabular}

Notes: ${ }^{* *} \mathrm{p}<0.01,{ }^{*} \mathrm{p}<0.05,{ }^{1}$ Likelihood-ratio test of rho=0, Probability (rho $>=$ chibar2) $=0.000$ 